\title{
Inquiry Method in the Teaching and Learning Process
}

\section{OPEN ACCESS}

Manuscript ID:

EDU-2020-08032396

Volume: 8

Issue: 3

Month: June

Year: 2020

P-ISSN: 2320-2653

E-ISSN: 2582-1334

Received: 17.03.2020

Accepted: 18.05.2020

Published: 01.06.2020

Citation:

Shanmugavelu, Ganesan,

Balakrishnan Parasuraman, et al. "Inquiry Method in the Teaching and Learning Process." Shanlax International Journal of Education, vol. 8, no. 3, 2020, pp. 6-9.

DOI:

https://doi.org/10.34293/ education.v8i3.2396

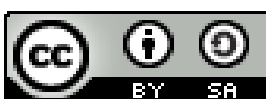

This work is licensed under a Creative Commons Attribution-ShareAlike 4.0 International License

\section{Ganesan Shanmugavelu}

Senior Lecturer of History, Institute of Teacher Education (Ipoh Campus), Malaysia

https://orcid.org/0000-0001-9961-0121

\section{Balakrishnan Parasuraman}

Professor of Industrial Relation and Human Resources, Universiti Malaysia Kelantan, Malaysia

\section{Khairi Ariffin}

Associate Professor of History, Sultan Idris Education University, Malaysia

\section{Baskaran Kannan}

Senior Lecturer of Education, Institute of Teacher Education Ipoh Campus, Malaysia

\section{Manimaran Vadivelu}

Senior Lecturer of Science Education, Institute of Teacher Education (Ipoh Campus), Malaysia

\section{Abstract}

The aim of this study is to discuss the use of the inquiry method in the teaching and learning process. The inquiry method is a student-centered learning approach with the concept of students who are actively involved in the teaching and learning activity under the monitoring and supervision of teachers. This study describes how to implement the inquiry method in the classroom. Five aspects such as planning behavioral objectives, designing teaching materials, designing questioning strategies, designing teaching and learning strategies, and evaluating are emphasized in the designing of the inquiry method in the teaching and learning process. Teaching and Learning based on the inquiry method is an approach that helps students build their knowledge and understanding through research and exploration activities based on existing knowledge. The inquiry method requires higher-order thinking skills and critical thinking to make conclusions. Besides that, teachers play a vital role in the success of the inquiry method for the realization of educational reforms.

Keywords: Inquiry, Method, Teacher, Teaching, Learning.

\section{Introduction}

The teaching method is a way for teachers to present their teaching in the classroom. This method is the essence of teaching and learning in the social science program to develop the learning skills that are meaningful to students. (Abdul Rahim Abdul Rashid 1989: 147) The inquiry method is a studentcentered teaching and learning method. This method emphasizes knowledge related to "how" and not "about," which means how knowledge is acquired and not about knowledge.

The inquiry method is trying to instill curiosity among individuals about something. This method requires a student to question the truth and accuracy of the information obtained. The importance of this method requires students to make sense of what they have learned. According to Beyer B.K, Inquiry is one way of making out of what we experience. It requires thinking....it requires learners to make their meaning out of what they experience. ( Barry K.Beyer, 1971: 6). The philosophy of inquiry method is a process rather than contentoriented. It is conceptual instead of factual emphasis. It is student-centered, not teacher-centered. It is active, not passive. (Barry K.Beyer, 1971: 159) 
It can be explained that the inquiry method emphasizes four main aspects, namely, process oriented-not content, emphasis on concept-not facts, student-centered, and non-passive learning. The inquiry method also emphasizes reflective investigations and interesting findings in the teaching and learning process. What is emphasized in this method is that students no longer accept only what the teacher provides, but instead guide students to learn the right information?

What is important is that the inquiry method involves students as active thinkers, seekers, inquisitors, and processors of information gathered around them. This method is important for students to make decisions or find answers related to their guidance. In finding answers to problems, students need to use their thinking skills to find relevant evidence to conclude.

The inquiry method also involves the process of reasoning. According to Atan Long, this process is a way of obtaining conclusions or drawing conclusions based on many examples or related methods found through observation and the collection of details or data. From the details of the examples, it is possible to conclude or form a concept on the matter. (Atan Long, 1980: 220)

Through this method, it is hoped that students can instill curiosity among them. Students will also try to get relevant information about a study or event when they first become interested in it. They will search for evidence, gather evidence, types of evidence, find relevant information, and eventually make generalizations. The importance of the inquiry method is to encourage students to use logical minds on issues, problems, or knowledge and apply the knowledge with the present situation. (Abdul Rahim Abdul Rashid, 1989: 148)

In general, the inquiry method has three important goals. The first is to identify the essential elements of intellectual inquiry. In this regard, we will look at what a person shows in solving a problem or the ability to answer questions with systematic thinking. Second, to reinforce the teaching strategies developed for the process. The goal is to find teaching strategies that can help create a framework for daily teaching and the preparation of units or courses of teaching. Third, to analyze some of the implications of using such strategies for teachers, classrooms, and curriculum appropriateness. (Abdul Rahim Abdul Rashid, 1989: 148)

\section{Aspects of Planning in the Inquiry Method}

Before discussing more the implementation of the inquiry method, it is important to know some aspects that need to be emphasized in the design of the inquiry method. There are five aspects that need to be emphasized in the planning of the inquiry method.

\section{(a) Planning Behavioral Objective}

In the process of planning the inquiry method, teachers should focus on students' abilities. In this case, the teacher should be aware of the students' background and their ability to carry out the activities in the inquiry method. This is important because each student will go through specific processes in the inquiry process, and teachers also need to know about the abilities of the students in their different classes.

\section{(b) Designing Teaching Materials}

Teachers should also provide students with appropriate titles. At the same time, teachers should also ensure that the resources for a title are adequate and provide the resources needed to implement them. For example, teachers can provide appropriate reference materials to enable students to gather information. Reference materials may include reference books, textbooks, newspaper and magazine clippings, documents, maps, electronic media, and others.

\section{(c) Designing Questioning Strategies}

In the inquiry method, the questioning strategy is more important than the answer. In this case, the teacher should plan the questions that can guide the students towards the learning objectives they want to achieve. The questions submitted must be able to develop critical and creative thinking among students. Questions that are more complex and challenge students' thinking. There are three levels of questions (i) for information (Recall Questions), (ii) questions that require interpretation, and (iii) High-Level questions in which students are required to develop tentative answers. The questions usually begin with the question of 'why' then 'how' and so on. 


\section{(d) Designing Teaching and Learning Strategies}

Before implementing the inquiry method, teachers must be clear about what their students need to achieve and learn. Next, teachers should plan student activities according to specific steps. Teachers also need to instruct students to understand what they need to do. In this case, teachers can also decide whether the inquiry is to be conducted individually or in groups. If it's group work, teachers should take into account specific factors such as group size, group members of the same or different gender, problems to solve, and so on. In this regard, teachers need to be more democratic in the formation of groups. Also, teachers should consider the techniques and methods that will be used in teaching and learning. For example, teachers can use the discussion method within the group they have formed.

\section{(e) Evaluation}

Teachers should also know how to evaluate the inquiry process. Evaluation can be done through questions that students ask, how they perform in learning activities, and how they handle information. Evaluation can also be done using media or audio visual tools for viewing, listening, and analyzing.

\section{Implementation of the Inquiry Method}

The inquiry method can be implemented in a variety of ways in a classroom. According to Edwin Fenton (1967), there are six major steps in implementing the inquiry method, as described below.

1. Identify Problems and Information

2. Design Hypothesis

(a) Design analytical questions

(b) State the hypothesis

(c) Be aware of hypotheses formed

3. Identify the logic of the implications of the Hypothesis to the overall title.

4. Collecting Data and Information

(a) Determine what data is required

(b) Select or reject sources

5. Analyze, evaluate and interpret data or information

(a) Select Relevant Data

(b) Evaluate sources

(c) Interpreting Data or Information
6. Evaluating Hypothesis based on Data

(a) Modify the hypothesis, if necessary

(b) Start or state generalizations

\section{The Role of Teachers in the Inquiry Method}

Although the inquiry method is student-centered, it does require a lot of teacher involvement. The role of the teacher in the inquiry method is to be the primary mentor, advisor, and planner. In the early stages of the implementation of the inquiry, teachers should provide topics consistent with students' cognitive thinking and development so that they understand and are interested in a topic.

Teachers should also plan the objectives of their students' goals, looking for resources that can guide their students toward their goals. In this regard, teachers must also ensure that students use legitimate resources in their studies. Teachers can tell students where and how a resource is available for reference. This will help students find the right information if they are having trouble finding important information; students should do their research.

Besides that, teachers should encourage different interpretations of an idea so that not all the students give the same answers. Accordingly, the teacher will receive different answers from the students. Teachers should, therefore, be prepared to listen to and accept different responses from students to a problem. In this regard, teachers should create an atmosphere that promotes and strengthens the relationship or interaction between students and teachers and students with students. Also, teachers should help students through questions, comments, and suggestions so that students can gain additional knowledge.

\section{Conclusion}

The above discussion clearly shows that the inquiry method emphasizes student-centered learning, where students are required to look at problems and solve them. The importance is, this method can sharpen the thinking and give students a rich and immersive learning experience. This method can also instill learning and self-study among students. The inquiry method is very suitable and can be used effectively in the social studies classroom, for instance, in the teaching and learning of history and other subjects as well. 


\section{References}

Alper, Christi. "Embracing Inquiry-Based Instruction." Edutopia, 2016.

Andrini, Vera Septi. "The Effectiveness of Inquiry Learning Method to Enhance Students' Learning Outcome: A Theoritical and Empirical Review." Journal of Education and Practice, vol. 7, no. 3, 2016, pp. 38-42.

Beyer, Barry K. Inquiry in the Social Studies Classroom: A Strategy for Teaching. Charles E. Mevrell Publishing Co., 1971.

Long, Atan. Pedagogi: Kaedah Am Mengajar. Fajar Bakti, 1980.

MacKenzie, Trevor. "Bringing Inquiry-Based Learning Into Your Class.” Edutopia, 2016.

Massialas, Byron, G. and Chrales Cox. Inquiry in Social Studies. McGraw Hill, New York, 1966.
Michaeslis, J. Social Studies for Children in a Democracy. Prentice Hall, 1972.

Mohamad, B. Pengajaran Pembelajaran dan Gaya Pembelajaran, Universiti Tun Hussein Onn Malaysia, 2008.

Pedaste, Margus. "Phases of Inquiry-based Learning: Definitions and the Inquiry Cycle." Educational Research Review, vol. 14, 2015, pp. 47-61.

Rashid, Abdul Rahim Abdul. Strategi Pengajaran Sejarah KBSM. Fajar Bakti, 1989.

Teig, Nani. “More Isn't Always Better: The Curvilinear Relationship between InquiryBased Teaching and Student Achievement in Science." Learning and Instruction, vol. 56, 2018, pp. 20-29.

Walter E. Sistrunk and Robert C. Maxson. A Practical Approach to Secondary Social Studies. W.C. Brown Company Publishers, 1972.

\section{Author Details}

Dr. Ganesan Shanmugavelu, Senior Lecturer of History, Institute of Teacher Education (Ipoh Campus), Malaysia.

Email ID:drganesan68@gmail.com.

Dr. Balakrishnan Parasuraman, Professor of Industrial Relation and Human Resources, Universiti Malaysia Kelantan, MalaysiaEmail ID: balakrishnan@umk.edu.my.

Dr. Khairi Ariffin, Associate Professor of History, Sultan Idris Education University, Malaysia.

Email ID: Khairi.ariffin@fsk.upsi.edu.my.

Dr. Baskaran Kannan, Senior Lecturer of Education, , Institute of Teacher Education (Ipoh Campus), Malaysia. Email ID: baskaran@ipgmipoh.edu.my.

Manimaran Vadivelu, Senior Lecturer of Science Education, Institute of Teacher Education (Ipoh Campus), Malaysia,Email ID: manimaran@ipgmipoh.edu.my. 